\title{
ANALISIS KESALAHAN MAHASISWA PADA MATA KULIAH KALKULUS MATERI PERSAMAAN DIFERENSIAL BERDASARKAN METODE NEWMAN DITINJAU DARI KEMAMPUAN AWAL MATEMATIKA
}

\author{
ERLAN SISWANDI \\ Program Studi Teknik Lingkungan Sekolah Tinggi Teknik Lingkungan Mataram \\ E-mail: erllando.michelle@gmail.com
}

\begin{abstract}
ABSTRAK
Persamaan Diferensial merupakan salah satu materi pada mata kuliah Kalkulus. Pada materi ini, mahasiswa sering mengalami kesulitan dalam menyelesaikan soal sehingga terjadi kesalahan. Adapun kesalahan-kesalahan yang terjadi sangat penting untuk dipecahkan agar tidak terjadi kesalahan-kesalahan yang sama di kemudian hari. Penelitian ini bertujuan untuk mendeskripsikan jenis-jenis kesalahan yang dilakukan oleh mahasiswa pada mata kuliah Kalkulus materi persamaan diferensial ditinjau dari kemampuan awal matematika mahasiswa berdasarkan metode Newman. Jenis penelitian ini yaitu kualitatif deskriptif. Penelitian ini dilakukan dengan pendekatan studi kasus terhadap 3 mahasiswa program studi Teknik Lingkungan Sekolah Tinggi Teknik Lingkungan Mataram sebagai subjek penelitian. Teknik pengumpulan data menggunakan tes soal dan wawancara. Instrumen dalam penelitian ini yaitu peneliti sebagai instrumen utama dan instrumen bantu berupa soal pemecahan masalah kontekstual dan juga pedoman wawancara. Hasil dari penelitian ini menemukan bahwa jenis-jenis kesalahan yang dilakukan mahasiswa dengan kemampuan awal matematika tinggi yaitu kesalahan pengkodean, kemudian mahasiswa dengan kemampuan awal matematika sedang mengalami kesalahan proses penyelesaian dan kesalahan pengkodean, sedangkan mahasiswa dengan kemampuan awal matematika rendah mengalami kesalahan pemahaman, kesalahan transformasi, kesalahan proses penyelesaian, dan kesalahan pengkodean. Jadi, mahasiswa dengan kemampuan awal matematika tinggi lebih sedikit kesalahan jika dibandingkan mahasiswa dengan kemampuan awal matematika sedang dan rendah.
\end{abstract}

Kata Kunci: Analisis Kesalahan Newman, Persamaan Diferensial, Kemampuan Awal Matematika

\section{PENDAHULUAN}

Kalkulus merupakan salah satu mata kuliah yang wajib ditempuh oleh mahasiswa program studi Teknik Lingkungan. Garis besar materi yang dibahas pada mata kuliah Kalkulus cukup luas, salah satunya yaitu persamaan diferensial. Persamaan diferensial merupakan sebuah persamaan yang mengandung turunan fungsi. Persamaan diferensial dapat diaplikasikan di berbagai bidang seperti bidang teknologi dan sains. Contohnya pemanasan, pendinginan, perilaku arus listrik, penguapan, dan sebagainya.

Kalkulus merupakan salah satu mata kuliah yang dianggap sulit untuk dipahami oleh mahasiswa. Di samping mahasiswa dituntut untuk memiliki kemampuan awal matematika yang tinggi, mahasiswa juga harus memiliki kemampuan bernalar yang baik. Oleh sebab itu, di dalam proses pembelajaran, sering kali mahasiswa mengalami kesulitan dalam menyelesaikan soal sehingga menyebabkan terjadinya suatu kesalahan.

Berdasarkan hasil pretest saat awal perkuliahan Kalkulus, didapatkan masih banyaknya mahasiswa yang belum memahami konsep dasar turunan. Dari 19 mahasiswa yang diberikan soal turunan, didapatkan 7 mahasiswa mampu menjawab soal dengan benar dan 12 mahasiswa mengalami kesalahan. Ini artinya terdapat 37\% mahasiswa mengerjakan soal dengan benar dan $63 \%$ mahasiswa mengalami kesalahan. Kemudian saat diwawancara, kebanyakan dari mahasiswa menjawab sudah lupa dengan konsep dasar turunan, padahal waktu di Sekolah Menengah Atas telah diajarkan. Konsep dasar turunan merupakan konsep yang harus dipahami mahasiswa dalam mengerjakan soal persamaan diferensial. 
Persamaan diferensial merupakan salah satu materi yang dibahas pada mata kuliah Kalkulus. Untuk memudahkan mahasiswa memahami konsep persamaan diferensial dibutuhkan pembelajaran yang kontekstual. Pembelajaran kontekstual yaitu konsep pembelajaran yang mengaitkan materi yang diajarkan dengan kehidupan atau keadaan sehari-sehari mahasiswa. Oleh sebab itu, dengan sifat matematika yang abstrak memungkinkan untuk lebih mudah dipelajari apabila mahasiswa dihadapkan dengan pembelajaran yang kontekstual.

Sebelum melakukan proses pengajaran, seorang dosen perlu mengetahui kemampuan awal matematika mahasiswa agar dapat menentukan metode yang tepat dalam proses belajar mengajar. Berdasarkan hasil penelitian Nindiasari (2013) menyatakan bahwa salah satu faktor yang perlu diperhatikan dan akan berpengaruh terhadap pemerolehan pengetahuan selanjutnya adalah kemampuan matematika yang dimiliki sebelumnya. Kemampuan awal matematika terbagi menjadi tiga yaitu kemampuan awal matematika tinggi, sedang, dan rendah. Kemampuan awal matematika perlu dilihat apabila kita ingin melihat bagaimana kesalahan yang dilakukan oleh mahasiswa dalam pembelajaran. Dengan meninjau kemampuan awal matematika mahasiswa, maka bisa dilihat kesalahan apa yang mungkin dapat dilakukan oleh mahasiswa dengan kemampuan awal matematika tinggi, sedang, ataupun rendah.

Kesalahan-kesalahan yang dialami mahasiswa dalam mata kuliah Kalkulus perlu untuk dianalisis lebih lanjut. Hal ini ditujukan untuk memudahkan dosen dan mahasiswa dalam mengidentifikasi kelemahan proses pembelajaran dan mengatasi atau paling tidak mengurangi kesalahan-kesalahan berikutnya agar tidak terjadi kesalahan-kesalahan yang sama di kemudian hari. Metode analisis untuk mengetahui jenis kesalahan mahasiswa banyak macamnya. Salah satunya yaitu dengan menggunakan metode analisis Newman. Dalam metode ini, Newman menyarankan lima kegiatan untuk membantu dalam menemukan jenis kesalahan yang dialami mahasiswa ketika ketika berhadapan dengan soal matematika dalam hal ini yaitu soal persamaan diferensial. Menurut Febriani dan Mukhni (2018) bahwa analisis kesalahan Newman terdiri dari 5 tahapan, yaitu (1) Kesalahan membaca soal, (2) Kesalahan memahami soal, (3) Kesalahan konfigurasi soal, (4) Kesalahan keterampilan proses, dan (5) Kesalahan jawaban akhir. Jamal (2018) juga menyatakan bahwa jika dibandingkan dengan metode lain, metode Newman memiliki tingkat kredibilitas yang paling tinggi.

Pentingnya penelitian tentang analisis kesalahan mahasiswa pada mata kuliah Kalkulus materi persamaan diferensial, menyebabkan banyaknya peneliti yang tertarik untuk melakukan penelitian. Adapun penelitian-penelitian terdahulu yang serupa dengan penelitian ini yaitu penelitian yang dilakukan oleh Bulu (2020). Hasil penelitiannya menunjukkan mahasiswa dengan kemampuan pemecahan masalah matematika tinggi melakukan kesalahan dalam menuliskan jawaban akhir, mahasiswa dengan kemampuan pemecahan masalah matematika sedang melakukan kesalahan dalam mengubah masalah menjadi simbol matematika, dan mahasiswa dengan kemampuan pemecahan rendah mengalami kesalahan dalam mengubah simbol, selama proses, dan menulis jawaban akhir. Kemudian penelitian Farhan \& Zulkarnain (2019) menunjukkan bahwa kesalahan yang sering terjadi pada tahap reading, transformasi, dan process skill, yang meliputi kesalahan memahami soal, kesalahan menentukan formula yang tepat, kesalahan konsep (kesalahan menentukan turunan aljabar dan trigonometri, proses eliminasi dan substitusi, serta kesalahan dalam manipulasi bentuk aljabar fungsi gamma).

Berbeda dengan penelitian terdahulu, pada penelitian ini peneliti ingin melihat jenis-jenis kesalahan mahasiswa pada materi persamaan diferensial dengan menggunakan soal kontekstual, serta peneliti ingin melihat perbedaan jenis kesalahan yang dilakukan oleh mahasiswa dengan kemampuan awal matematika tinggi, sedang, dan rendah. Adapun tujuan dari penelitian ini yaitu untuk mendeskripsikan jenis-jenis kesalahan yang dilakukan oleh mahasiswa pada mata kuliah Kalkulus materi persamaan diferensial ditinjau dari kemampuan awal matematika mahasiswa berdasarkan metode Newman. 


\section{METODE PENELITIAN}

Penelitian ini merupakan penelitian kualitatif deskriptif dengan jenis studi kasus. Penelitian ini dikenakan kepada mahasiswa semester III program studi Teknik Lingkungan di Sekolah Tinggi Teknik Lingkungan (STTL) Mataram. Pemilihan subjek dilakukan dengan purposive sampling yang didasarkan pada pertimbangan-pertimbangan yaitu: (1) masing-masing subjek mewakili kategori kemampuan awal matematika tinggi, sedang, atau rendah setelah diberikan tes soal uraian; (2) subjek telah diberikan materi persamaan diferensial; (3) subjek mampu berkomunikasi dengan baik; (4) subjek tidak merasa ditekan atau dipaksa. Berdasarkan pertimbangan-pertimbangan tersebut, dipilih 3 subjek dari 19 mahasiswa. 1 mahasiswa memiliki kemampuan awal matematika tinggi, 1 sedang, dan 1 rendah. Subjek penelitian berdasarkan kategori kemampuan awal matematika dapat dilihat pada Tabel 1. berikut:

Tabel 1. Subjek Penelitian Berdasarkan Kategori Kemampuan Awal Matematika

\begin{tabular}{cccc}
\hline No & $\begin{array}{c}\text { Inisial } \\
\text { Subjek }\end{array}$ & Nilai & Kemampuan Awal Matematika \\
\hline 1 & MAK & 81 & Tinggi \\
\hline 2 & YSR & 67 & Sedang \\
\hline 3 & MBJ & 43 & Rendah \\
\hline
\end{tabular}

Pengumpulan data dilakukan dengan pemberian tes soal dan wawancara kepada subjek penelitian. Instrumen yang digunakan dalam penelitian ini yaitu instrumen utama dan instrumen bantu. Instrumen utama adalah peneliti sendiri dan didukung oleh instrumen bantu yaitu berupa soal kontekstual persamaan diferensial dan juga pedoman wawancara.

Analisis data pada penelitian ini berdasarkan model Miles dan Huberman (1992), yakni reduksi, penyajian atau display data, serta kesimpulan atau verifikasi. Tahap-tahap ini tidak harus dilakukan berurutan tergantung kebutuhan data. Sugiyono (2013) menyatakan bahwa analisis data kualitatif dilakukan secara interaktif dan berlangsung terus menerus sampai tuntas sehingga datanya jenuh. Tahap-tahap analisis model Miles dan Huberman dalam penelitian ini dijabarkan menjadi langkah-langkah yaitu: (1) Membuat transkrip wawancara dari hasil rekaman. (2) Menelaah hasil pekerjaan subjek dan hasil wawancara. (3) Mereduksi data atau membuang data yang tidak dibutuhkan. (4) Membuat satuan-satuan analisis data dan memberi pengkodean. (5) Menganalisis dan menggambarkan kesalahan-kesalahan mahasiswa dalam menyelesaikan soal kontekstual persamaan diferensial. (6) Menafsiran data. (7) Melakukan triangulasi data. (8) Menuliskan hasil penelitian.

Untuk mengidentifikasi jenis-jenis kesalahan yang dilakukan mahasiswa, dapat dilakukan dengan melihat langkah-langkah penyelesaian yang dibuat mahasiswa dalam menyelesaikan tes soal. Untuk mempermudah peneliti dalam mengidentifikasi jenis-jenis kesalahan tersebut, maka peneliti menyusun indikator-indikator kesalahan sesuai klasifikasi Newman's Error Analysis (White, 2010) seperti pada Tabel 2. berikut.

\section{Tabel 2. Indikator Kesalahan Newman}

\begin{tabular}{lll}
\hline Jenis-jenis Kesalahan & \multicolumn{1}{c}{ Indikator Kesalahan } \\
\hline Kesalahan Membaca & 1) & $\begin{array}{l}\text { Salah dalam membaca soal materi persamaan } \\
\text { diferensial dan tidak paham arti kalimat dalam soal } \\
\text { tersebut. }\end{array}$ \\
& 2) $\begin{array}{l}\text { Tidak mampu membaca dengan benar soal } \\
\text { persamaan diferensial. }\end{array}$ \\
3) & $\begin{array}{l}\text { Dapat membaca dengan benar akan tetapi tidak bisa } \\
\text { mengambil informasi yang penting dalam soal } \\
\text { persamaan diferensial. }\end{array}$ \\
&
\end{tabular}


\begin{tabular}{ll}
\hline Kesalahan Pemahaman & 1) Tidak bisa menentukan apa yang diketahui dan apa \\
(Comprehension Error) & yang ditanyakan dari soal persamaan diferensial.
\end{tabular}

2) Salah dalam menentuan apa yang diketahui dan apa yang ditanyakan dari soal persamaan diferensial.

3) Tidak mengunakan informasi atau belum menangkap informasi yang terkandung dari soal persamaan diferensial.

Kesalahan 1) Salah dalam menentukan langkah-langkah Transformasi (Transformation Error) penyelesaian dan langkah-langkah mana yang didahulukan dalam menyelesaikan soal persamaan diferensial.

2) Salah dalam menentukan rumus yang digunakan dalam langkah-langkah penyelesaian soal persamaan diferensial.

3) Salah dalam menentukan model matematika dari soal persamaan diferensial.

Kesalahan Proses Penyelesaian (Process Skills Error)

1) Salah dalam mengoperasikan perhitungan dalam menyelesaiakan soal persamaan diferensial terlepas dari kesalahan sebelumnya.

2) Salah dalam menentukan sistematika penyelesaian soal matematika kontekstual materi persamaan diferensial.

3) Salah dalam menentukan operasi hitung dalam menyelesaikan soal persamaan diferensial.

Kesalahan

Pengkodean/Penentuan

Jawaban Akhir

(Encoding Error)
1) Salah dalam menentukan jawaban akhir ataupun tidak menentukan jawaban akhir dari soal persamaan diferensial.

2) Salah dalam menentukan kesimpulan ataupun tidak menentukan kesimpulan dari jawaban akhir soal persamaan diferensial.

3) Siswa salah karena proses sebelumnya dan tidak menentukan satuan pada jawaban akhir dari soal persamaan diferensial.

Validitas data yang digunakan dalam penelitian ini yaitu teknik triangulasi. Yenusi, Mumu, dan Tanujaya (2019) menyatakan bahwa triangulasi adalah teknik pemeriksaan data yang memanfaatkan sesuatu lain di luar data itu untuk keperluan pengecekan atau pembanding terhadap data itu. Triangulasi yang digunakan dalam penelitian ini yaitu triangulasi waktu, dengan cara melakukan pengecekan wawancara dan observasi dalam waktu atau situasi yang berbeda terhadap subjek penelitian. Jika hasil ujinya menghasilkan data yang berbeda, maka dilakukan lagi secara berulang-ulang sampai didapatkan kepastian data.

\section{HASIL DAN PEMBAHASAN}

Pengambilan data dimulai dengan pemberian tes soal kontekstual materi persamaan diferensial pada subjek penelitian. Hasil jawaban subjek kemudian dianalisis dan dilakukan wawancara mendalam untuk mengklarifikasi jawaban subjek. Dari hasil analisis kemudian dilakukan pengelompokkan jenis-jenis kesalahan berdasarkan metode Newman, yaitu (1) Kesalahan Membaca (Reading Error), (2) Kesalahan Pemahaman (Comprehension Error), (3) Kesalahan Transformasi (Transformation Error), (4) Kesalahan Proses Penyelesaian (Process 
Skills Error), dan (5) Kesalahan Pengkodean (Encoding Error). Adapun hasil analisis kesalahan subjek ditinjau dari kemampuan awal matematika dapat dilihat sebagai berikut.

\section{A. Subjek dengan Kemampuan Awal Matematika Tinggi}

Subjek dengan kemampuan awal matematika tinggi dalam penelitian ini yaitu MAK. Subjek terlebih dahulu diberikan soal kontekstual materi persamaan diferensial, kemudian subjek diminta untuk menjawab soal yang diberikan. Hasil pekerjaan/jawaban subjek dapat dilihat pada Gambar 1. berikut.

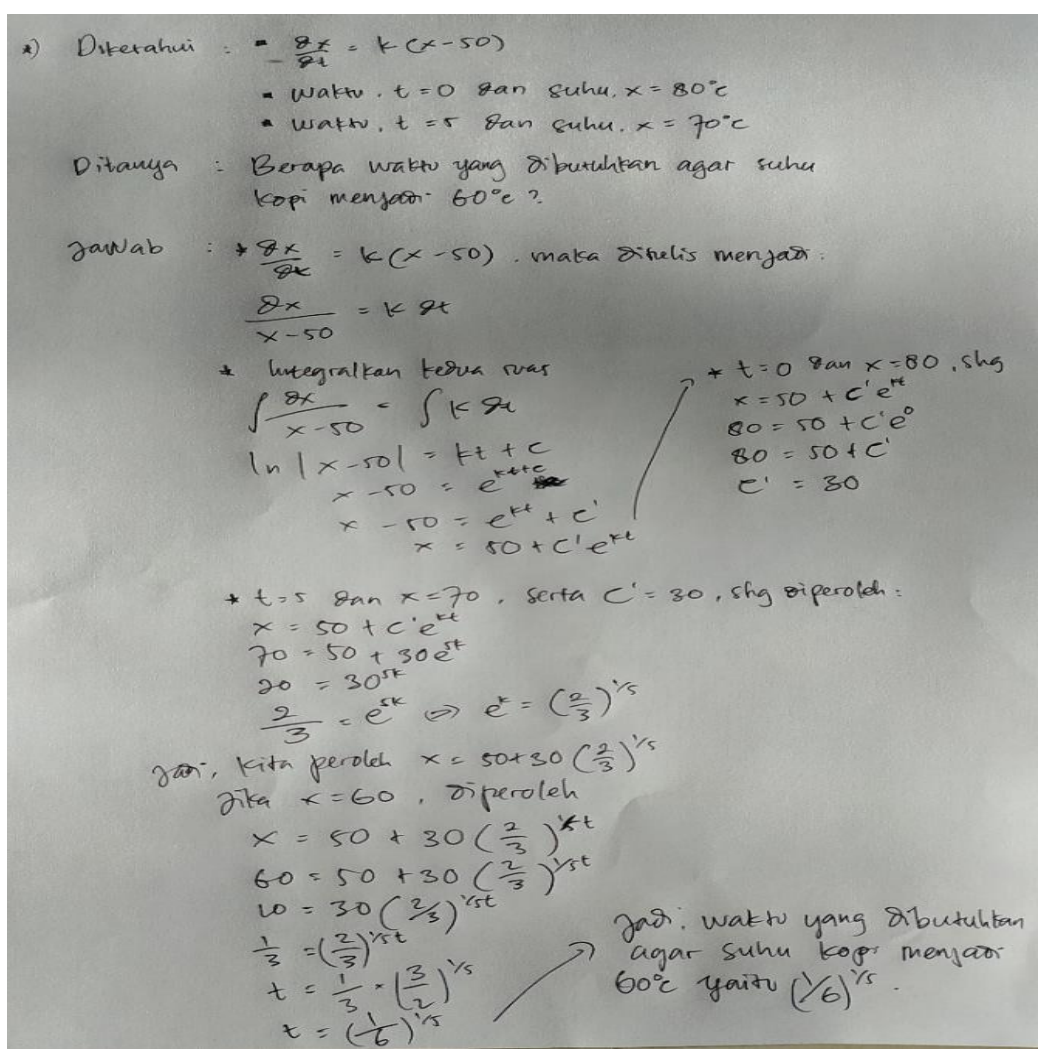

Gambar 1. Hasil Jawaban Subjek MAK

Berdasarkan Gambar 1. di atas, terlihat bahwa subjek MAK memahami soal dengan benar. Hal ini terlihat ketika subjek mampu menuliskan apa yang diketahui dan apa yang ditanyakan dari soal serta mampu menuliskan simbol-simbol matematika dengan benar. Saat diwawancara subjek juga mampu membaca soal, mampu menjelaskan kembali soal yang dibaca dan mampu mengambil informasi yang penting dari soal.

Pada Gambar 1. terlihat juga subjek MAK mampu menentukan langkah-langkah penyelesaian dan langkah-langkah mana yang didahulukan dalam penyelesaian, serta mampu menentukan rumus yang digunakan. Kemudian ketika diwawancara subjek MAK dapat menjelaskan rumus-rumus penyelesaian dan dapat menjelaskan langkah-langkah yang benar dalam menyelesaikan soal. Pada proses penyelesaian, subjek MAK terlihat mampu mengoperasikan perhitungan dalam menyelesaikan soal serta mampu menentukan operasi hitung dalam menyelesaikan soal. Saat diwawancara, subjek MAK tidak kesulitan ketika diminta menjelaskan pengoperasian perhitungan dan menentukan operasi hitung dalam menyelesaikan soal. Pada proses penentuan jawaban akhir, subjek MAK mengalami kesalahan dalam menentukan jawaban, salah dalam menentukan kesimpulan, dan tidak menuliskan satuan. Dari hasil wawancara, subjek menyampaikan bahwa subjek sudah lupa dengan materi logaritma sehingga mengalami kesulitan dalam mengubah pangkat ke bentuk logaritma dan menyebabkan kesalahan dalam menentukan 
jawaban akhir dan kesalahan dalam menentukan kesimpulan. Kemudian untuk satuannya, subjek MAK juga lupa untuk menuliskan karena kurangnya ketelitian. Dari hasil triangulasi yang telah dilakukan baik dari tes soal kontesktual maupun wawancara, didapatkan bahwa subjek MAK mewakili kategori kemampuan awal matematika tinggi mengalami kesalahan menyelesaikan soal kontektual pada materi persamaan diferensial pada penentuan jawaban akhir. Sehingga, kesalahan ini termasuk ke dalam jenis kesalahan pengkodean (encoding error).

Kesalahan pengkodean (encoding error) yang dilakukan oleh mahasiswa dengan kemampuan awal matematika tinggi disebabkan karena mahasiswa tidak paham (telah lupa) bagaimana konsep logaritma, sehingga mengalami kesulitan saat mengubah pangkat ke bentuk logaritma. Selain itu, kurangnya ketelitian juga menjadi penyebab dari kesalahan pengkodean ini. Hal ini sejalan dengan penelitian Juliant dan Noviartati (2016); Febriani dan Mukhni (2018) yang menyampaikan bahwa subjek sulit untuk memahami soal karena tidak memahami konsep yang berkaitan dengan materi tersebut juga tidak fokus dalam mengerjakan soal tersebut.

\section{B. Subjek dengan Kemampuan Awal Matematika Sedang}

Subjek dengan kemampuan awal matematika sedang dalam penelitian ini yaitu YSR. Subjek terlebih dahulu diberikan soal kontekstual, kemudian subjek diminta untuk menjawab soal tersebut. Hasil pekerjaan/jawaban subjek dapat dilihat pada Gambar 2. berikut.

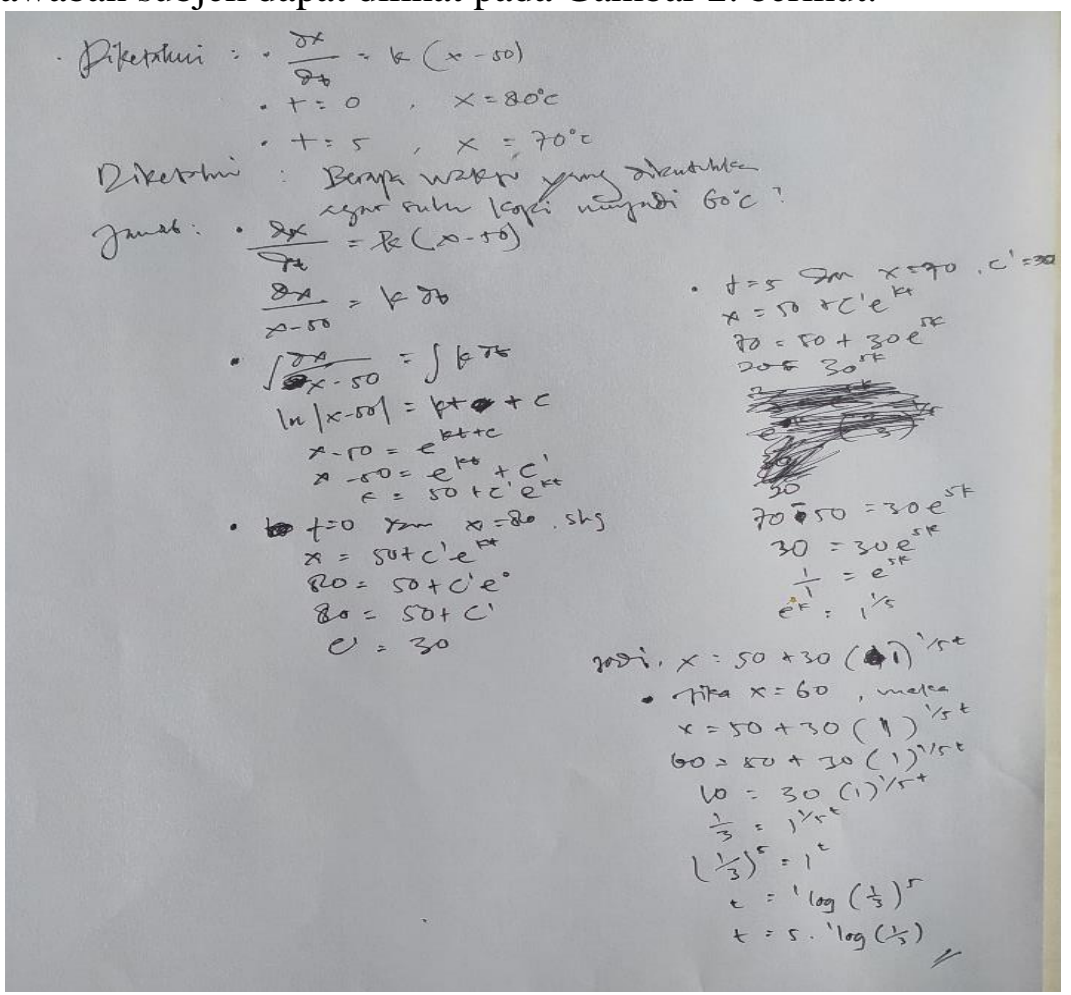

Gambar 2. Hasil Jawaban Subjek YSR

Berdasarkan Gambar 2. di atas, terlihat bahwa subjek YSR memahami soal dengan benar. Subjek mampu menuliskan apa yang diketahui dan apa yang ditanyakan dari soal yang diberikan, serta mampu menuliskan simbol-simbol matematika dengan benar. Ketika diwawancara dan diminta membaca soal, subjek juga mampu membaca soal dengan baik, mampu menjelaskan kembali maksud dari soal yang dibaca dan mampu mengambil informasi penting dari soal tersebut.

Pada Gambar 2. juga menunjukkan bahwa subjek YSR mampu menentukan menentukan rumus yang digunakan, mampu menentukan langkah-langkah penyelesaian dan langkah-langkah mana yang didahulukan dalam penyelesaian. Saat diwawancara, subjek YSR dapat menjelaskan rumus-rumus penyelesaian yang digunakan dengan benar dan dapat menguraikan langkah-langkah 
dalam menyelesaikan soal secara tepat.

Pada proses penyelesaian, subjek YSR terlihat mengalami kesalahan dalam pengoperasian perhitungan. Saat diwawancara dan diminta untuk menjelaskan pengoperasian perhitungan, subjek YSR tidak mampu menjelaskan dengan benar dan terjadi miskonsepsi. Hal ini memicu kesalahankesalahan berikutnya yaitu kesalahan pada penentuan jawaban akhir.

Pada penentuan jawaban akhir, subjek YSR mengalami kesalahan dalam menentukan jawaban, tidak menuliskan kesimpulan, dan tidak menuliskan satuan. Saat diwawancara, subjek mengatakan bahwa subjek bingung ketika dihadapkan dengan soal perpangkatan, apalagi pangkatnya bilangan pecahan. Selain itu subjek juga tidak mampu memberikan kesimpulan dan juga satuan dari jawabannya karena subjek tidak terbiasa menuliskan kesimpulan.

Berdasarkan teknik triangulasi yang telah dilakukan baik dari tes soal kontesktual maupun wawancara, didapatkan bahwa subjek YSR mewakili kategori kemampuan awal matematika sedang, mengalami kesalahan menyelesaikan soal kontektual materi persamaan diferensial pada proses penyelesaian dan penentuan jawaban akhir. Sehingga, kesalahan ini termasuk ke dalam jenis kesalahan proses penyelesaian (process skills error) dan kesalahan pengkodean (encoding error).

Kesalahan proses penyelesaian (process skills error) yang dilakukan oleh mahasiswa dengan kemampuan awal matematika sedang disebabkan karena mahasiswa mengalami miskonsepsi terhadap pengoperasian perhitungan. Kemudian kesalahan pengkodean (encoding error) disebabkan karena mahasiswa kesulitan ketika dihadapkan dengan soal perpangkatan dan juga tidak terbiasa menuliskan kesimpulan. Hal ini sejalan dengan penelitian Farida (2015) yang menyatakan bahwa siswa tidak terbiasa menuliskan kesimpulan dari suatu pertanyaan.

\section{Subjek dengan Kemampuan Awal Matematika Rendah}

Subjek dengan kemampuan awal matematika rendah dalam penelitian ini yaitu MBJ. Subjek diberikan soal kontekstual terlebih dahulu, kemudian subjek diminta untuk menjawab soal tersebut. Hasil pekerjaan/jawaban subjek dapat dilihat pada Gambar 3. berikut.

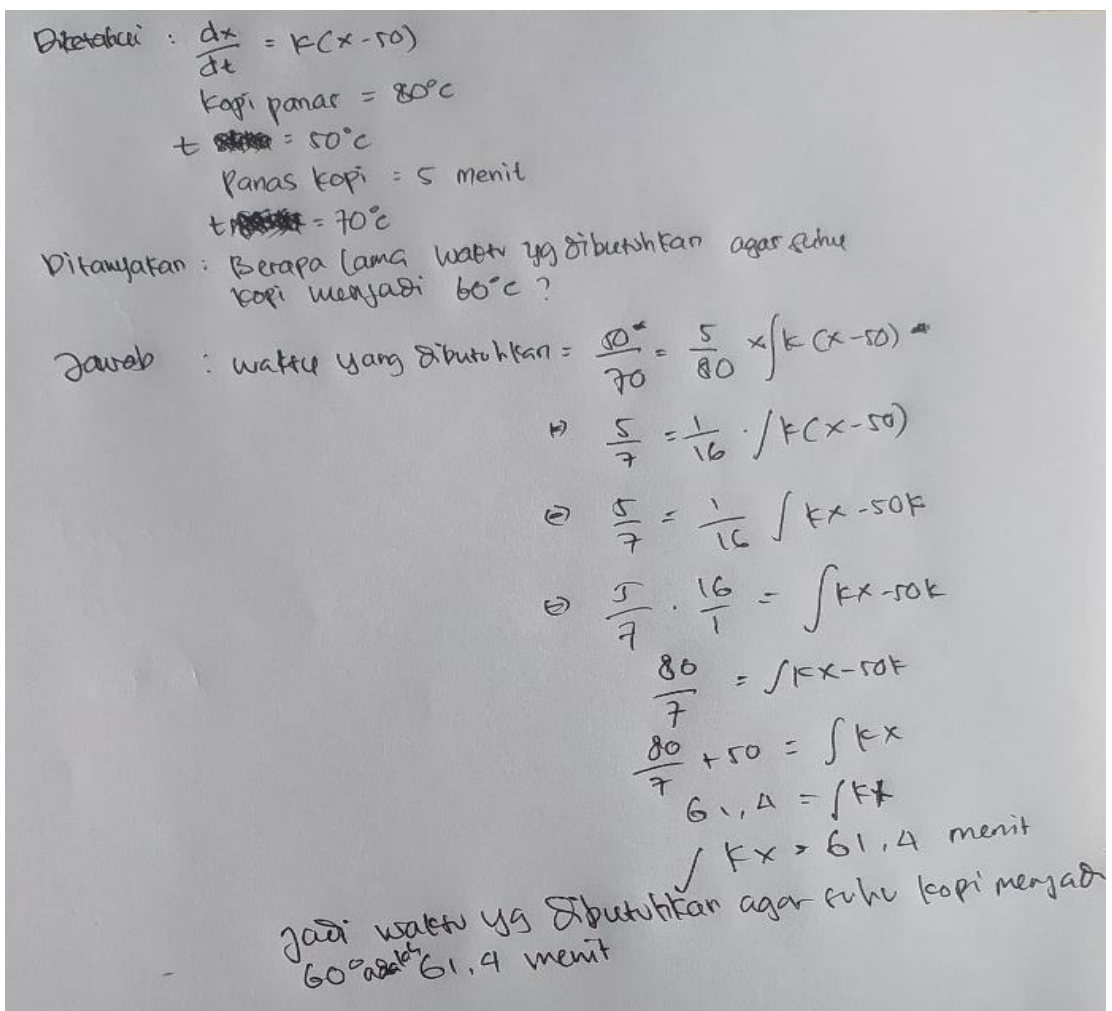

Gambar 1. Hasil Jawaban Subjek MBJ 
Berdasarkan Gambar 3. di atas, terlihat bahwa subjek MBJ tidak memahami soal dengan benar. Hal ini terlihat pada subjek yang mengalami kesalahan menuliskan apa yang diketahui dari soal yang diberikan, subjek juga tidak mampu menuliskan simbol-simbol matematika dengan tepat. Akan tetapi, saat diwawancara dan diminta membaca soal, subjek mampu membaca soal dengan baik, mampu menjelaskan kembali maksud dari soal yang dibaca dan mampu mengambil informasi penting dari soal tersebut. Kesalahan menuliskan apa yang diketahui dari soal disebabkan ketidakpahaman subjek dalam memahami isi kandungan soal yang diberikan. Kesalahan inilah yang memicu terjadinya kesalahan-kesalahan selanjutnya.

Pada Gambar 3. juga menunjukkan subjek MBJ tidak mampu menentukan rumus yang digunakan, tidak mampu menentukan langkah-langkah penyelesaian dan langkah-langkah mana yang didahulukan dalam penyelesaian. Saat diwawancara, subjek MBJ tidak dapat menjelaskan terkait rumus-rumus penyelesaian yang digunakan dan tidak dapat menguraikan langkah-langkah dalam menyelesaikan soal secara tepat.

Pada proses penyelesaian, subjek MBJ mengalami kesalahan dalam pengoperasian perhitungan. Saat diwawancara dan diminta untuk menjelaskan terkait perhitungan, subjek MBJ tidak paham bagaimana perhitungan dari integral dengan benar. Hal ini juga memicu kesalahankesalahan berikutnya yaitu kesalahan pada penentuan jawaban akhir.

Pada penentuan jawaban akhir, subjek MBJ mengalami kesalahan dalam menentukan jawaban dan salah dalam menuliskan kesimpulan. Ketika diwawancara, subjek mengatakan bahwa subjek tidak paham dan tidak terbiasa dengan soal-soal persamaan diferensial dan konsep integral, serta kesulitan dalam menghadapi permasalahan kontekstual.

Berdasarkan triangulasi yang telah dilakukan baik dari tes soal kontesktual maupun wawancara, didapatkan bahwa subjek MBJ mewakili kategori kemampuan awal matematika rendah, mengalami kesalahan menyelesaikan soal kontektual materi persamaan diferensial pada proses memahami soal, transformasi, proses penyelesaian, dan penentuan jawaban akhir. Sehingga, kesalahan ini termasuk ke dalam jenis kesalahan pemahaman (comprehension error), kesalahan transformasi (transformation error), kesalahan proses penyelesaian (process skills error) dan kesalahan pengkodean (encoding error).

Kesalahan pemahaman (comprehension error) yang dilakukan oleh mahasiswa dengan kemampuan awal matematika rendah disebabkan karena mahasiswa tidak paham dengan isi kandungan soal yang diberikan. Hasil penelitian Oktaviana (2018) dimana siswa yang tidak mampu memahami maksud dari soal merupakan penyebab kesalahan memahami siswa. Kesalahan transformasi (transformation error) disebabkan oleh ketidakmampuan mahasiswa dalam menentukan rumus yang digunakan, tidak mampu menentukan langkah-langkah penyelesaian dan langkah-langkah mana yang didahulukan dalam penyelesaian. Kesalahan proses penyelesaian (process skills error) disebabkan mahasiswa tidak paham bagaimana pengoperasian perhitungan dari integral dengan benar. Kesalahan pengkodean (encoding error) disebabkan karena mahasiswa tidak paham dan tidak terbiasa dengan soal-soal persamaan diferensial dan konsep integral, serta kesulitan dalam menghadapi permasalahan kontekstual. Hal ini sesuai dengan apa yang disampaikan Saputri, et.al (2018) yang menyatakan bahwa siswa tidak dapat menyelesaikan dengan menggunakan prosedur yang benar karena tidak terbiasa menyelesaikan soal sejenis.

Jika melihat hubungan antara kemampuan awal matematika mahasiswa dengan kesalahan yang dialami dalam menyelesaikan soal konstekstual pada mata kuliah Kalkulus materi persamaan diferensial, maka terlihat bahwa terdapat perbedaan kesalahan yang dialami masing-masing kategori kemampuan awal matematika. Hal ini sesuai dengan hasil penelitian Juliant dan Noviartati (2016) yaitu siswa dengan kemampuan tinggi, sedang dan rendah melakukan kesalahan yang berbeda-beda dalam menyelesaikan soal cerita pola bilangan. Dalam penelitiannya juga didapatkan bahwa semakin rendah kemampuan awal matematika matematika siswa maka akan semakin banyak kesalahan yang terjadi, dan begitu sebaliknya. 
Apabila dilihat dari penyebab terjadinya kesalahan, sebagian besar kesalahan yang dilakukan mahasiswa dalam menyelesaikan soal konstekstual pada mata kuliah Kalkulus materi persamaan diferensial di atas disebabkan karena mahasiswa tidak paham konsep dalam menyelesaikan soalsoal kontekstual materi persamaan diferensial. Hal inilah yang sangat berdampak atau memicu terjadinya suatu kesalahan.

\section{KESIMPULAN}

Kemampuan awal matematika mahasiswa memiliki hubungan dengan kesalahan yang dialami mahasiswa dalam menyelesaikan soal kontekstual pada mata kuliah Kalkulus materi persamaan diferensial. Mahasiswa dengan kemampuan awal matematika tinggi lebih sedikit mengalami kesalahan jika dibandingkan mahasiswa dengan kemampuan awal matematika sedang dan rendah. Jenis kesalahan yang dilakukan mahasiswa dengan kemampuan awal matematika tinggi yaitu kesalahan pengkodean (encoding error), kemudian mahasiswa dengan kemampuan awal matematika sedang mengalami kesalahan proses penyelesaian (process skills error) dan kesalahan pengkodean (encoding error), sedangkan mahasiswa dengan kemampuan awal matematika rendah mengalami kesalahan pemahaman (comprehension error), kesalahan transformasi (transformation error), kesalahan proses penyelesaian (process skills error) dan kesalahan pengkodean (encoding error).

\section{DAFTAR PUSTAKA}

Bulu, V. R. (2020). Analisis Kesalahan Mahasiswa dalam Menyelesaikan Soal Cerita Berdasarkan Metode Newmann. Journal Of Honai Math, 3(1), 41-56. DOI: http://doi.org/10.30862/jhm.v3il.111

Farhan, M., \& Zulkarnain, I. (2019). Analisis Kesalahan pada Mata Kuliah Kalkulus Peubah Banyak Berdasarkan Newmann's Error Analysis. Jurnal Kajian Pendidikan Matematika, 4(2), 121-134.

Farida, N. (2015). Analisis Kesalahan Siswa SMP Kelas VIII Dalam Menyelesaikan Masalah Soal Ceita Matematika. AKSIOMA: Jurnal Program Studi Pendidikan Matematika, 4(2), 42-52.

Febriani, D. E., \& Mukhni. (2018). Analisis Kesalahan Siswa dalam Menyelesaikan Soal Cerita Matematika Berdasarkan Analisis Kesalahan Newman pada Siswa Kelas VIII SMP Negeri

7 Padang. Jurnal Edukasi dan Penelitian Matematika, 7(4), 24-29.

Jamal, F. (2018). Analisis Kesalahan dalam Menyelesaikan Soal Cerita Pertidaksamaan Kuadrat Berdasarkan Prosedur Newmann, Jurnal Maju, 5(2), 41-51.

Juliant, A., \& Noviartati, K. (2016). Analisis Kesalahan Siswa dalam Menyelesaikan Soal pada Materi Pola Bilangan Ditinjau dari Kemampuan Matematika Siswa. Jurnal Riset Pendidikan, 2(2), 111-118.

Miles, M. B., \& Huberman, A. M. (1992). Analisis Data Kualitatif diterjemahkan oleh Tjetjep Rohendi Rohidi. Jakarta: UI Press.

Nindiasari, H. (2013). Meningkatkan Kemampuan dan Disposisi Berpikir Reflektif Matematis serta Kemampuan Belajar Siswa SMA Melalui Pembelajaran dengan Pendekatan Metakognitif. Unpublished Disertasi. Bandung: Universitas Pendidikan Indonesia.

Oktaviana, D. (2018). Analisis Tipe Kesalahan Berdasarkan Teori Newman Dalam Menyelesaiakan Soal Cerita Pada Mata Kuliah Matematika Diskrit. Edu Sains: Jurnal Pendidikan Sains \& Matematika, 5(2), 22. DOI:https:/doi.org/10.23971/eds.v5i2.719

Saputri, R. R., Sugirarti, T., Murtikusuma, R.P., Trapsilasiwi, D., \& Yudianto, E. (2018). Analisis Kesalahan dalam Menyelesaikan Materi Fungsi Berdasarkan Kriteria Warson Ditinjau dari Perbedaan Gender Siswa SMP Kelas VIII. Kadikma, 9(2), 59-68.

Sugiyono. (2013). Metode Penelitian Kuantitatif, Kualitatif, dan R\&D. Bandung: Alfabeta. 
White, A. L. (2010). Numeracy, Literacy, and Newman's Error Analysis. Journal of Science and Mathematics Education in Southeast Asia, 33(2), 129:148.

Yenusi, T., Mumu, J., \& Tanujaya, B. (2019). Analisis Soal Latihan pada Buku Paket SMA yang Bersesuaian dengan Higher Order Thinking Skill. Journal of Honai Math, 2(1), 53-64. 